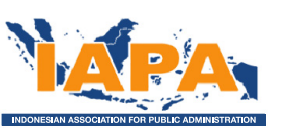

\begin{tabular}{r|l} 
POLICY\&GOVERNANCE & PGR
\end{tabular}

\author{
Agung Wicaksono \\ Indonesia - National Disaster Management Authority, Disaster Management Analyst \\ Email: wicaksono.agung@bnpb.go.id
}

Submitted: 11 August 2020, Revised: 24 September 2020, Accepted: 21 September 2020

\section{Agung Wicaksono}

is a disaster management analyst in national disaster management authority. He was born on 31st August 1985 in Jakarta. Since 2010, he has worked focus on community development in disaster preparedness issue. In 2020 Graduated from Master Public Administration in Faculty of Social and Political Sciences, Universitas Gadjah Mada. Agung Wicaksono also joined memberships among other things Incident Command System Master Trainer, Disaster Community Resilience Program Facilitator and Professional Certification Institution - Disaster Management.
Policy \& Governance Review ISSN 2580-4820

Vol. 4, Issue 3, pp. 224-244

DOI: https://doi.org/10.30589/pgr. v4i3.354

\title{
Examining Inter-organizational Network during Emergency Response of Gunungkidul Drought 2019
}

\begin{abstract}
Drought is a disaster that often occurs in Gunungkidul Regency, where the condition was exacerbated by the occurrence of a long drought in 2019 (BMKG, 2019). Beside climatic and geological factors, drought is also caused by the involvement of multi-stakeholders, including local governments in managing drought emergency conditions. This research presented a case study on drought disaster management in Gunungkidul in 2019, where qualitative and social network analysis research methods were applied. Social network analysis was used to examine the central actors of the organizations involved in drought management and the role of networks in these levels of government. Meanwhile, qualitative methods were used to explore the factors influencing the network. The results show that the central actors during the emergency response were BPBD, PMI, and PDAM of Gunungkidul Regency. Meanwhile, the role of inter-organizational networks at the district level had been optimized by performing command and control over developments in the situation, involving community organizations and business institutions. Furthermore, on the factors affecting the network, everything had been maximized except two factors that were still lacking, including partnerships and the use of sophisticated information technology.
\end{abstract}

\section{Keywords:}

Inter-organizational networks; emergency response; disaster; drought

\section{Introduction}

Disasters always shackle human life; even in the last ten years, the intensity of catastrophic events has continued to increase (BNPB, 2014). According to Fritz (1961), disasters are events that are concentrated in time and space, where people experience physical damage and social disruptions so that all or some of the essential functions of society experience disturbances. Similarly, UNISDR (2009) defined a disaster as a severe disruption in society that affects people, their physics, economics, or nature. This disorder is also considered causing serious damage that exceeds people's ability to solve this problem by using their strategy. Furthermore, Gregg and Houghton (2006) linked disasters with the inability of 
local communities to deal with bad influences of the issues and the need for external assistance.

Disaster is strongly related to the concept of before (pre), during, and after (post) events. Experts argue from that point of view that there is a cycle of action as disaster management to address the problems. These steps originate from prevention, mitigation, preparedness, response, and recovery (Lindell, Prater, \& Perry, 2007).

Disaster management includes plans, structures, and arrangements, which involve the efforts of government, volunteers, and private parties in a coordinated and comprehensive manner to respond to all emergency needs. Therefore, disaster management consists of all planning, organizing, and mobilizing the resources needed to handle all phases of a disaster as a particular natural event (Kelly, 1995 in Kusumasari 2014).

The government in carrying out effective disaster management, particularly in the emergency phase, according to McEntire (2002), must develop networks with other institutions, improve relations between governments and multi-organizations, and learn from agencies of disaster and emergency management from other countries. Multi-stakeholder cooperation is reliable in solving a public issue when the capability of the local government is insufficient to control the emergency.

According to Kusumasari (2014), capability in managing disasters is reflected as a function of institutional capability, human resource capability, policy for effective implementation, financial capability, technical capability, and leadership capability (Figure 1). Besides, operational capabilities are transformed into factors for the success of the disaster management process. Schreyogg (in Kusumasari 2014) reinforced that the capability is essential for the organization to have because it is identified as one of the main sources for the competitive generation and development, uncertainty, and environmental changes. Therefore, networking and coordinating with other parties becomes crucial when the key source of these capabilities cannot be fulfilled.

Figure 1.

\section{Government Capability Model in Disaster Management}

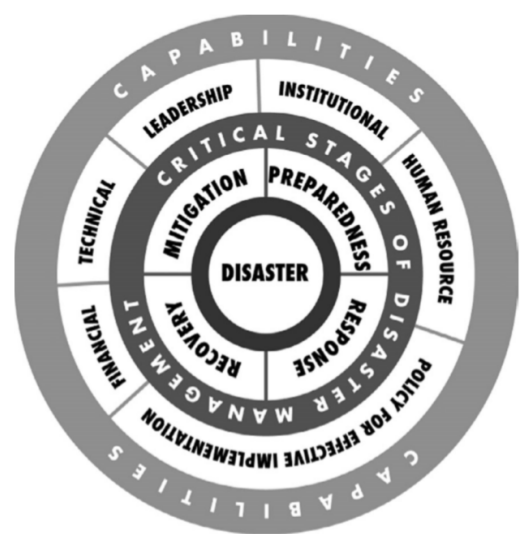

Source: Kusumasari, Alam, Siddiqui, 2010

A crisis management system consisting of multiple agencies and organizations will be able to adapt more effectively to threats in a particular area than separate and uncoordinated efforts by disaster authorities to meet the same vision and challenges. That way public organizations adapt by forming networks (Comfort, 1999)

Kaufman (1993) analyzed this as a complex adaptive system that relies on an information infrastructure with an adequate structure for storing and exchanging information but is flexible enough to adapt to changing circumstances. The key to this concept is self-organization, or the ability to reallocate resources and actions in order to respond to the changing demands of the environment.

Comfort (1999) in her research investigated four types of adaptive systems that were identified in the field study of emergency response systems, including non-adaptive systems, emergent adaptive systems, operative adaptive systems, and auto-adaptive systems.

Non-adaptive systems are low in technical structure, organizational flexibility, and cultural 
openness to new information. They function under threats relying mostly on outside support but return to their former status after threatening events.

Emergent adaptive systems are characterized by being low in technical structure, moderate in organizational flexibility, and moderate in a cultural openness to new concepts of both operations and organization. Such systems develop modes of organization and action to address threats during disaster operations, but cannot sustain collective action once the threat has passed.

Operative adaptive systems are those at a moderate level in the technical structure, organizational flexibility, and cultural openness to new information. These systems function well in response to threats but prove incapable to translate response methods into new modes of continuous operation and threat reduction.

Auto-adaptive systems are those that are high in technical structure, organizational flexibility, and cultural openness to new information. Such a system is a rare accomplishment, but in practice, it has proven to be effective in responding to threats and capable of transferring lessons learned from previous experiences into continuous threat reduction. Regarding the unlimited threat of uncertainty, such as terrorism, the preferred type of adaptation is the auto-adaptive systems that can learn from incoming information, reallocate their resources and attention, rearrange their relationships with other entities, and act immediately to reduce threats or respond to destructive actions.

The exponentially increasing number of disasters mandates every stakeholder to be better prepared for a powerful event. Multi-stakeholder participation can return to normalcy in a short time. This is possible with the trust and strength of affected communities who not only survive severe disasters but also assist in emergency response operations. Good coordination efforts from various government agencies and organizations have made it possible to effectively implement humanitarian assistance (Meduri, 2016).

This is as asserted by Twigg (2015) who assessed the importance of holistic disaster response from multi-stakeholders and various disciplines and institutional groups, although not implemented in many cases. According to him, the failure of multistakeholder cooperation is caused by disaster specialists and technical people who tend to act separately when working in long-term, sustainable emergency response in development programs.

Djalante (2012) considered the role of multistakeholders in disasters using the governance approach as a more innovative and integrated approach in addressing complex problems caused by disasters. The government system is "less rigid, less uniform, less prescriptive and less hierarchical, and promise a more innovative but effective way of dealing with complex environmental problems" (Holley, 2010 in Djalante, 2012).

Koppenjan and Klijn (2004) classified three types of challenges in multi-stakeholder cooperation. First, substantive uncertainty can be defined as a lack of knowledge about the problem or an excess of non-definitive information, leading to a blurring of the main problem. Second, strategic uncertainty arises because the network involves several actors who maintain some (considered) strategic matters and create uncertainty about the choices they will make. Lastly, institutional uncertainty, is the dominance of one actor over another, arising from the efforts to try to coordinate actors who have particular perceptions, norms, and goals, with those from different institutional backgrounds, administrative levels, or organizations.

In Indonesia, the discussion regarding the development of inter-organizational networks during an emergency has become highly insightful since no area is free from disasters. According to data collected in the Indonesian Disaster Information and Data (DIBI) (BNPB, 2016), 
there were more than $78 \%(11,648)$ incidents of hydrometeorological disasters in the period 2005 to 2015 and only about $22 \%(3,810)$ of geological disasters (Figure 1). Hydrometeorological disaster groups occur as floods, extreme waves, land and forest fires, drought, and extreme weather. Meanwhile, geological disasters that often occur include earthquakes, tsunamis, volcanic eruptions, and landslides. The trend of the total number of disaster occurrences for the two groups is relatively increasing.

The number of disasters caused by geological factors is not too significant compared to those caused by hydrometeorological factors. Nonetheless, geological disasters, particularly earthquakes and tsunamis, cause quite large impacts both in terms of casualties and economic losses.

Figure 2.

Graph of Disaster in 2005 - 2015

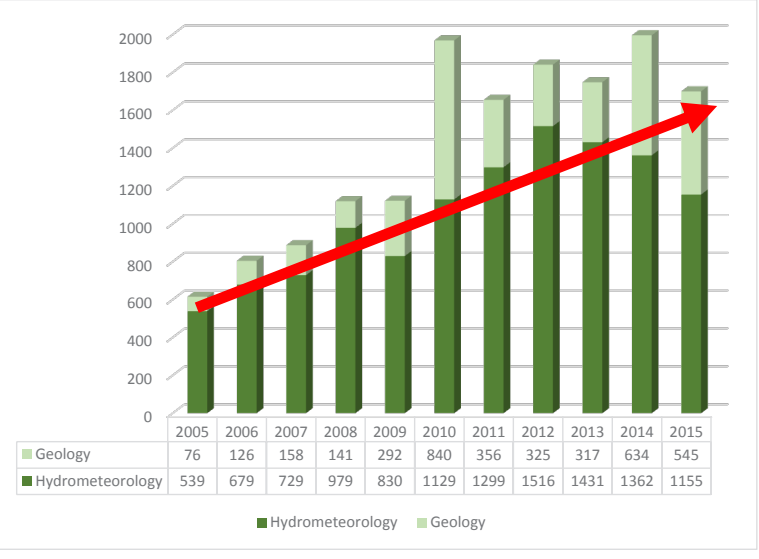

Source: BNPB, 2016

The effects of climate change also contribute to an increase in the incidence of hydrometeorological disasters. Human activities such as forest encroachment for plantations and settlements or construction activities that affect ecosystems and ecology in buffer areas worsen the environmental conditions (BNPB, 2016). Hydrometeorological conditions involving landslides, forest and land fires, disease outbreaks, floods, and drought become the factor of the imminent danger (UNISDR, 2009).
Hydrometeorological disaster group, such as drought, has a huge direct and indirect impact, particularly on the economic and environmental sectors. Drought is caused by climatic anomalies, combined with low antecedent storage in surface and subsurface systems, which can lead to water deficits in the hydrological cycle, and thus result in hydrological drought (Tallaksen et al., 2015)

FAO (2017) identified three main types of drought that can occur separately or together. First, environmental drought. This occurs when a lack of rainfall is believed to be bad for the environment. It is likely to lead to reduced river flow, extremely low groundwater levels, and insufficient soil moisture. Second, agricultural drought. This occurs when there are inadequate rainfall and soil moisture to support crop production or agricultural practices like irrigation. Third, water supply drought. This occurs when a lack of rainfall causes water companies to be concerned about supply to their customers. It takes longer to develop compared to environmental or agricultural droughts because water company supply systems were developed to cope with dry weather.

Gunungkidul Regency is an area prone to experiencing drought each year, particularly the water supply drought. This water problem is essential to be resolved because almost annually, more than 100 thousand people are affected by this episode. In 2018, drought hit 54 villages in 11 districts, impacting about 116,216 inhabitants. Disaster Management Agency of Gunungkidul Regency dropped water to the affected areas and had not yet been supplied by the Local Water Company (PDAM) (BPBD, 2018).

In 2019, as a result of the prolonged drought, the number of people affected by drought continued to increase compared to the previous year. A total of fifteen districts were affected by the drought, including Rongkop, Girisubo, Tepus, Purwosari, Panggang, Nglipar, Patuk, Ngawen, Ponjong, Semin, Semanu, Paliyan, Karangmojo, Tanjung Sari, and Gedang Sari. The total number 
of affected residents reached 130,000. The three worst areas included Girisubo District with a total of 21,718 affected inhabitants, Paliyan District with six villages of 16,978 inhabitants, Rongkop District with eight villages of 9,922 inhabitants, and Tepus District with five villages of 12,441 inhabitants (BPBD, 2019).

Apart from climatic factors due to the prolonged dry season, the drought was also caused by the geological conditions of Gunungkidul Regency in the form of karst and limestone. The rock formations in Gunungkidul Regency consist of massive coral reef limestone in the south and layered limestone in the north (Adhi, 2011). Gunungkidul Regency is part of the karst of the Sewu Mountains. The karst develops in relatively thick carbonate rocks which allows the development of underground karst formations, although the impermeable bedrock is not too deep. This one characteristic of Gunungkidul Regency causes this area to be considered prone to drought since a dry season with a longer time than usual will cause drought to occur very easily. This is because shallow groundwater reserves are relatively small compared to other areas due to the thin solum of soil in this karst area (Prasetyo, 2013).

Based on the preliminary description above, this study examined in depth the network in emergency response. The authors used an approach of inter-organizational networks to determine extensively the roles of actors in responding to drought as a problem-solving process. This network analysis used the Social Network Analysis (SNA) approach to observe the general condition of the network and the roles of actors in the network.

RQ1. How are the inter-organizational networks of drought management and who are the central actors, as seen through the Social Network Analysis approach (SNA)?

RQ2. How is the role of the network at the government level?
RQ3. What are the factors that affect the inter-organizational networks of drought management?

\section{Methods}

This study used Social Network Analysis and qualitative descriptive research methods. This study aimed to map the role of social networks among organizations that respond to drought in Gunungkidul Regency, Yogyakarta Province. The data required in network research varies from statistical data, network graphics, to qualitative descriptions. A combination of research with a quantitative approach, which is further deepened with a qualitative one, will, therefore, provide a deeper understanding than a single approach.

Social networks are defined as patterns of social interactions that take place among actors within a given scope. They are formed by a series of actors (members of the network) who in certain types of relationships are interrelated. The study of social networks which puts the initial premise that social life is created from relations and patterns of a relationship are defined from the interaction between units is a basic component of network theory (Wasserman \& Faust, 1994).

In analyzing social networks, a particular method is needed, in this case, was Social Network Analysis (SNA), which places the relationship among actors as the key to the analysis. SNA has several definitions. While Krebs (2008) defined SNA as a process of mapping and measuring relationships among people, Freeman (2004) defined it as a technique that focuses on studying unexposed patterns of interaction in humans. Further, Scott and Carrington (2011) defined SNA as a set of methods to investigate aspects of relations in social structures. An outline of the similarities can be drawn on the basis of the three existing definitions, in which the Social Network Analysis emphasizes the form, structure, and interaction patterns of the entities within it. SNA emphasizes the interactions among the entities 
within it rather than the entities themselves. Alternatively stated, it discusses the relationships among actors rather than the attributes of these actors because the patterns of interaction between entities will provide new information. Actors here can refer to individuals or organizations.

Prell (2012) explained that SNA can be used to measure whether actors involved in the network are popular, peripherals, or good mediators, and can see the actors' roles in certain contexts. Understanding how individual actors are situated within a particular network can, therefore, help understand questions such as who matters in the network, makes things happen on the network, or holds the network together in hard times. If certain actors in a network appear to have more resources than others, understanding the social networks around that individual might explain how that actor can play a central role in the network. Centrality measures are some of the initial attempts to begin to uncover the question 'who matters in the network?', which is also the most 'popular' and widely used measure for complete networking.

Inter-organizational networks during the emergency response of drought in Gunungkidul Regency were analyzed using several data in a complete network, including degree centrality, closeness centrality, and betweenness centrality. The selection of the study design was tailored to the research needs, which was to examine the general network conditions and the roles of the network actors.

This study took the population of organizations involved in drought disaster response in Gunungkidul Regency using the results of preliminary preresearch interviews with the Gunungkidul Regency Disaster Management Agency (BPBD). Organizations that were initially involved, such as BPBD, PMI, Social Service, Public Works Service, PDAM, PAMESKARTA, and 18 Districts in Gunungkidul Regency. As a first step, the authors mapped the existence and activeness of these organizations. It followed by a search for the possibility of involvement of other organizations in the drought response in Gunungkidul Regency. As a result, the authors found 48 organizations that participated in the drought response, covering government organizations, community organizations, or business institutions.

The research took place in Gunungkidul Regency. The selection of this area was due to data from the Indonesia Disaster Risk Index in 2013 (BNPB, 2013), that the district had an extremely high threat of disasters, one of which was the drought that has occurred to date.

The research sample was taken using a survey method, which was carried out to all organizations found from the initial mapping results. Representatives of each organization were the direct chairpersons or administrators who could represent. This survey served to find out about the attributes of each organization and basic data related to the networks of each organization which would be processed into a network graph.

The first survey was related to basic information regarding organizations in Gunungkidul Regency. The second was a survey concerning social networks in response to drought in Gunungkidul. The form of questions related to this network used a roster format, where the authors provided the names of the organizations from the initial observation with the BPBD. The roster format allows respondents to remember all possible names of network members (Borgatti, Everett, and Johnson, 2013)

The number of relationships developed by organizations is not determined or free choice, indicating that each organization is free to state how many relationships are formed with other actors (Wasserman and Faust, 1994). The indicator used in the network survey is which actors the organization has networked with in drought response.

Network graphs were analyzed using the Social Network Analysis method through UCINET-NetDraw 6.0 software that can be used 
on Windows and IOS. The authors input data in the form of a collection of information obtained from the survey results only.

Besides using the SNA method, this study utilized a qualitative approach. They were applied because the authors tried to portray the description of the research area and understand the factors affecting the inter-organizational network during the emergency response of drought. A qualitative approach was used with the intention of understanding the phenomena experienced by research subjects such as behavior, perception, motivation, action, et cetera, as a whole and employing descriptions in a specific natural context, often by utilizing various scientific models (Moleong, 2005).

\section{Results and Discussion}

BMKG Yogyakarta Climatology Station (2019), in the document of the 2019/2020 Rainy Season Forecast in DI Yogyakarta, predicted that the start of the 2019 rainy season in DI Yogyakarta Province was estimated to be in November 2019 (weeks 1-3) and the nature of the rainy season was estimated at $50 \%$ below normal and $50 \%$ were normal. When compared with the 30 -year average (1981-2010), the initial forecast for the 2019/2020 rainy season was entirely backward 1-2 dasarian (ten consecutive days). Based on the table below, Gunungkidul Regency was the last regency in starting the 2019 rainy season.

Figure 3 shows the drought risk map for Gunungkidul Regency. It can be seen that areas shaded with red, orange, light green, and dark green have very high, high, low, and very low risk of drought, respectively. The northern area of Gunungkidul Regency is difficult to access in the process of providing clean water because the area has many steep road contours so it requires the excellent condition of water trucks.

In the dry season in 2019 in Gunungkidul Regency, at least 135 thousand residents lacked clean water, spread over 14 districts, consisting of 78
Table 1.

Forecast of the Start of the 2019 Rainy

Season

\begin{tabular}{|c|c|}
\hline $\begin{array}{c}\text { Start of the } \\
\text { Rainy Season }\end{array}$ & Description \\
\hline \multirow{4}{*}{$\begin{array}{c}\text { Dasarian of } \\
\text { November } \\
1-3\end{array}$} & $\begin{array}{l}\text { Kulon Progo Regency (most part } \\
\text { of Temon, Kokap, Pengasih, and } \\
\text { Girimulyo Districts, all Wates, } \\
\text { Panjatan, Galur, Lendah, amd Sentolo } \\
\text { Districts) } \\
\text { Sleman Regency (small part of } \\
\text { eastern Ngaglik and southeastern } \\
\text { Mlati Districts, most part of Turi, } \\
\text { Pakem, Cangkringan, Gamping, } \\
\text { Depok, and Ngemplak Districts, all } \\
\text { Kalasan, Berbah, and Prambanan } \\
\text { Districts) }\end{array}$ \\
\hline & All districts in Yogyakarta Province \\
\hline & $\begin{array}{l}\text { Bantul Regency (most part of } \\
\text { Sedayu District, all Piyungan, } \\
\text { Dlingo, Banguntapan, Imogiri, } \\
\text { Pundong, Kretek, Pajangan, Pandak, } \\
\text { Srandakan, Sanden, Bambanglipuro, } \\
\text { Jetis, Bantul, Sewon, Kasihan, and } \\
\text { Pleret Districts) }\end{array}$ \\
\hline & $\begin{array}{l}\text { Gunungkidul Regency (all Semanu, } \\
\text { Gedangsari, Ngawen, Ponjong, } \\
\text { Wonosari, Playen, Patuk, Nglipar, } \\
\text { Semin, Karangmojo, Purwosari, } \\
\text { Panggang, Saptosari, Tanjungsari, } \\
\text { Tepus, Girisubo, and Rongkop } \\
\text { Districts) }\end{array}$ \\
\hline
\end{tabular}

Source: BMKG Yogyakarta Climatology Station (2019)

villages. The total budget for clean water assistance was IDR 530 million or equivalent to 2,000 clean water tanks, consisting of 5 to 6 thousand liters of water each tank, which was estimated to run out before the rainy season came (BPBD, 2019).

The limited regular budget in responding to the drought emergency in Gunungkidul Regency could be resolved by submitting an unexpected budget from the APBD of Gunungkidul Regency. Besides, the local government could also request assistance from the Provincial Government of the Special Region of Yogyakarta and the Central Government. However, this condition was not implemented by BPBD of Gunungkidul Regency, considering the many partners in the drought 
Figure 3.

Drought Risk Map of Gunungkidul Regency

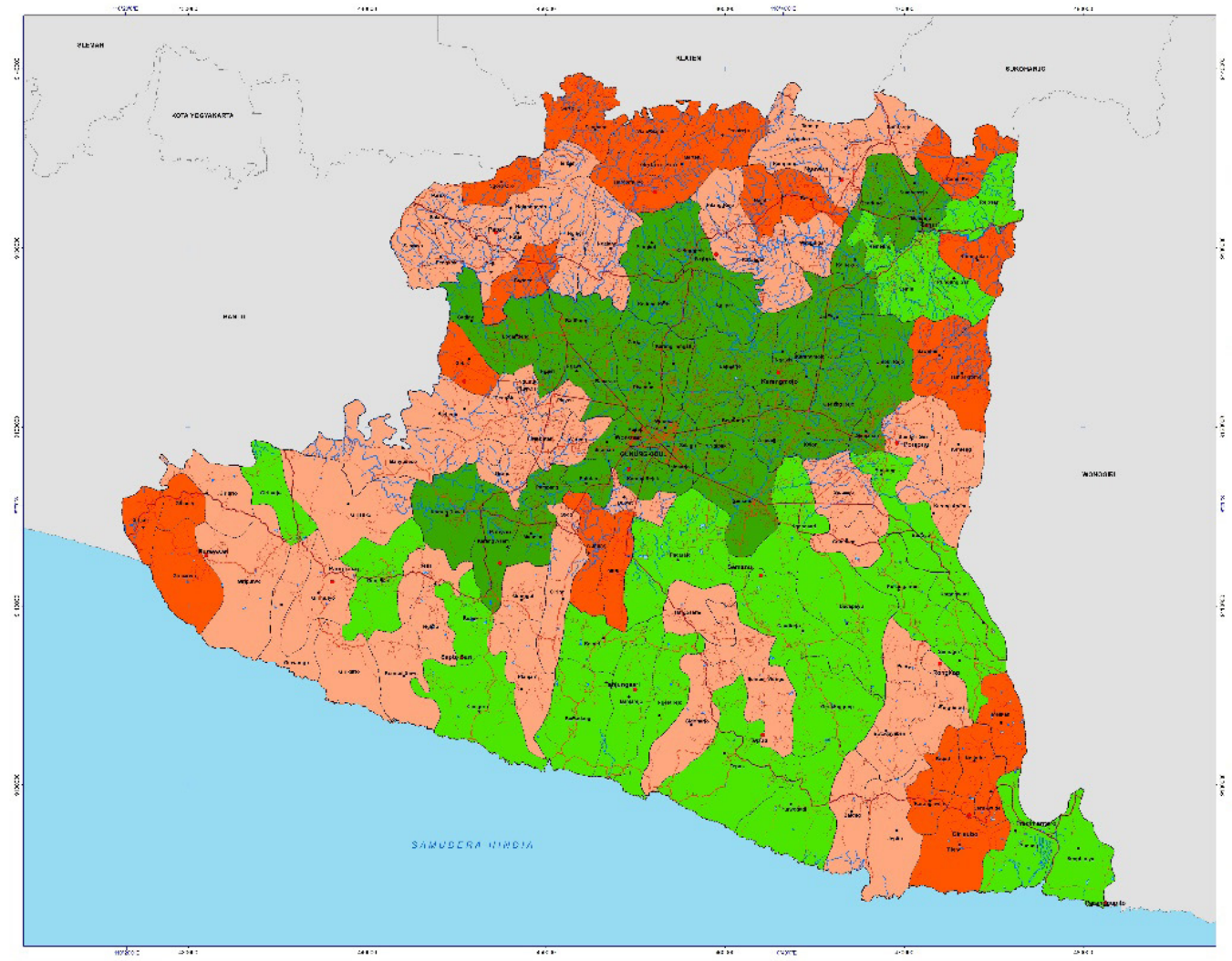

PETA RISIKO KEKERINGAN KABUPATEN GUNUNGKIDUL PROVINSI D.I. YOGYAKARTA

南

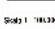

(-i)

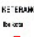

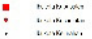

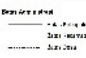

$=$

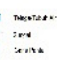

傿:

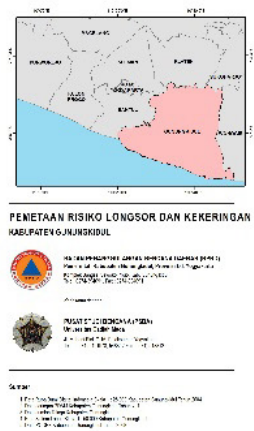

Source: BPBD Gunungkidul (2016)

disaster management network. Based on the results of this study, 48 organizations involved in the drought response, ranging from the government, business organizations, communities, and nongovernment organizations (NGOs).

Regarding the mentioned networking capability, Comfort (1999) referred to as a mode of adaptation in an inter-organizational response system (complex adaptive system). It can be identified in the system for interorganizational networks emerging in response to each type of danger. This characterization of interorganizational networks in drought response includes the type of operative adaptation shown in the system of organizational flexibility to function well in response to threats but is less successful in operating response methods sustainably and reducing the imminent danger.

\section{Central Actors in Inter-Organizational Networks}

By looking at the graph of interorganizational networks, the authors used the SNA analysis tool of UCINET 6.0. The initial step was giving a value of " 0 " for actors who had no relationship and " 1 " for those who had a relationship. The results of the social network graph at the end of the emergency response phase (2-20 September 2019) are provided in the figure below. Based on the analyzed dataset, the positions of actors/organizations including central government, provincial governments, district governments, business institutions, communities, universities, and NGOs acted as actors in emergency response activities.

Figure 4 indicates that the units in the Gunungkidul Regency Government structure 
seemed to dominate the interaction of drought emergency response activities. Organizations involved in the main network had a crucial role and were a vital element in the emergency period. It is clear from the picture that the central actor in this graph pointed to three actors, including BPBD Gunungkidul Regency, PMI, and PDAM of Gunungkidul. Meanwhile, organizations on the periphery/outside network complemented the existing deficiencies in organizations on the main network. This is in accordance with the roles of each level of government. Prell (2012) explained that actors in the peripheral network are generally connected to those in the main network only. Meanwhile, those in the main network are connected to all other network members including actors in the peripheral network.

Furthermore, the central actors in the interorganizational network were analyzed. Several statistical measures were carried out to analyze the characteristics of actors/organizations in the network. The measures chosen for this analysis were degree centrality (the extent to which the degree of centrality of actors was evenly distributed across the network), betweenness centrality (the extent to which dependence on other actors was evenly distributed across the network), and closeness centrality (how close they were to other members). UCINET 6.0 software was utilized in the calculation process. Based on the three calculation processes, it was found that the actors with high centrality were the Regional Disaster Management Agency of Gunungkidul Regency, the Indonesian Red Cross Society of the headquarter of Gunungkidul Regency, and the Local Water Company of Gunungkidul Regency. The interpretation using the Social Network Analysis (SNA) is as follows.

A centralized inter-organizational network is extremely useful for the initial phase of a disaster in forming groups and building support for collective action. However, centralized networks also have unfavorable disadvantages for long-term planning and problem solving, given the drought

Figure 4.

Graph of Inter-Organizational Networks in Emergency Response of Drought in Gunungkidul Regency

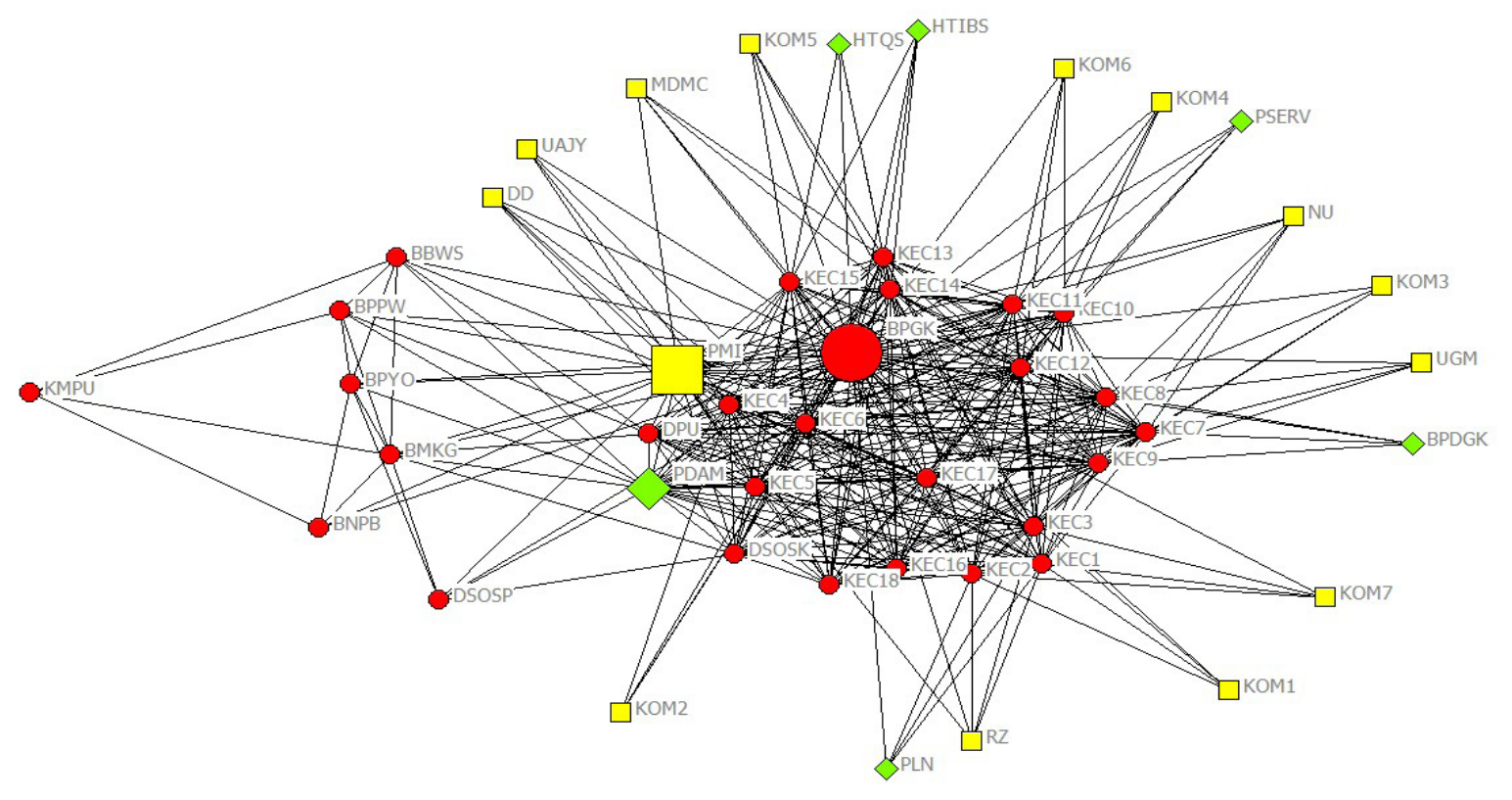

Sumber: Processed by the Authors 
disaster is a type of slow onset and prolonged disaster. This long-term planning requires a more decentralized network structure: one has more ties, either weak or strong, among more actors and stakeholder categories (Crona and Bodin, 2006 in Prell, 2009).

\section{Degree Centrality}

The results of degree centrality measures are shown in the table below. It can be seen the ten actors/organizations with the highest centrality, including the Regional Disaster Management Agency (BPBD) of Gunungkidul Regency, the Indonesian Red Cross Society of the Headquarter of Gunungkidul Regency, PDAM, KEC 15 (Rongkop District), KEC 7 (Girisubo District), KEC 2 (Tepus District), KEC 9 (Panggang District), KEC 1 (Paliyan District), KEC 8 (Purwosari District), and KEC 3 (Semin District). In short, the top ten consists of district government agencies, local NGOs, local government-owned enterprises, and district level government agencies.
Based on the degree centrality, it seems that the network was highly centralized to the Regional Disaster Management Agency of Gunungkidul Regency, with a degree of centrality reaching 46,000 . However, this value might be more than expected since network ties were the sum of all types of cooperation, sharing of resources, exchange of knowledge, et cetera. It should be noted that many districts were involved in the drought response process because they had quite severe levels of drought. This was indicated by the high demand for clean water distribution from the district, none of the shallow well water locations and the minimal access from the PDAM to reach the districts.

The high degree of centrality achieved by the BPBD of Gunungkidul Regency is suspected to be because most of the resources flow to the BPBD which worked and was directly responsible for controlling the drought disaster situation, either donation resources or sharing knowledge information. Besides, each district always

Table 2.

Degree Centrality Measures

\begin{tabular}{|c|c|c|c|c|}
\hline \multicolumn{5}{|c|}{ DEGREE CENTRALITY MEASURES } \\
\hline \multicolumn{2}{|c|}{ OutDegree } & \multirow{2}{*}{$\begin{array}{r}\text { InDegree } \\
\\
- \\
-0.000\end{array}$} & \multirow{2}{*}{$\begin{array}{r}\text { NrmOutDeg } \\
\\
97.872\end{array}$} & \multirow{2}{*}{$\begin{array}{r}\text { NrmInDeg } \\
-------- \\
97.872\end{array}$} \\
\hline BPBD & 46.000 & & & \\
\hline PMI & 32.000 & 32.000 & 68.085 & 68.085 \\
\hline PDAM & 27.000 & 27.000 & 57.447 & 57.447 \\
\hline KEC15 & 26.000 & 26.000 & 55.319 & 55.319 \\
\hline KEC7 & 26.000 & 26.000 & 55.319 & 55.319 \\
\hline KEC2 & 26.000 & 26.000 & 55.319 & 55.319 \\
\hline KEC9 & 26.000 & 26.000 & 55.319 & 55.319 \\
\hline KEC1 & 26.000 & 26.000 & 55.319 & 55.319 \\
\hline KEC8 & 26.000 & 26.000 & 55.319 & 55.319 \\
\hline KEC3 & 26.000 & 26.000 & 55.319 & 55.319 \\
\hline
\end{tabular}

Source: Processed by the Authors 
coordinated with the BPBD when the clean water reserves in the community were running low and requested for clean water. Therefore, this is also one of the reasons for the high value of degree centrality.

Likewise, the degree centrality of PMI of the headquarter of the Gunungkidul Regency reached 32,000 , which was almost dominated by requests for water distribution, cooperation in donations for aid, and information transfer. As a local government-owned enterprise, PDAM ranks third in terms of degree centrality, where most of its work was receiving complaints from the public from each district.

It is in line with Prell's (2012) explanation that degree centrality is seen as a measure of the level of "involvement or activity" of actors in the network, not considering whether the actor is seen as influential or popular. In a network, actors with a high degree of centrality are those that can be considered as the main channel for information in a particular network. These actors talked to many other people, and thus heard and spread new information quickly.

\section{Betweenness Centrality}

In terms of betweenness centrality, the BPBD of Gunungkidul Regency also ranks the highest with a score of 364,733 because of its role as a liaison institution, where all actors (government and non-government) before carrying out emergency response activities must contact, obtain permission, and cooperate with the BPBD of Gunungkidul Regency. Likewise, PMI also obtained a high level of betweenness centrality with a score of 71,233 because several donor agencies that would provide assistance had good relations with PMI before finally having to coordinate with the BPBD of Gunungkidul Regency. Meanwhile, activities carried out by PDAM were related to the distribution of clean water supply.
Table 3.

Betweenness Centrality Measures

\begin{tabular}{|lcc|}
\hline \multicolumn{3}{c|}{ BETWEENNESS CENTRALITY MEASURES } \\
& Betweenness & nBetweenness \\
& ---------- & ------- \\
BPBD & 364.733 & 33.740 \\
PMI & 71.233 & 6.590 \\
PDAM & 28.067 & 2.596 \\
KEC15 & 19.350 & 1.790 \\
KEC7 & 19.350 & 1.790 \\
KEC2 & 19.350 & 1.790 \\
KEC9 & 19.350 & 1.790 \\
KEC1 & 19.350 & 1.790 \\
KEC8 & 19.350 & 1.790 \\
KEC3 & 19.350 & 1.790 \\
\hline
\end{tabular}

Source: Processed by the Authors

In this case, Prell (2012) explained that betweenness centrality occurred as an actor is placed between two disconnected actors, which will provide certain advantages. If the intermediary actors are removed or eliminated, the network will fall apart. Betweenness centrality is considered essential because it relates to the control of a network.

Figure 5 indicates that when the central actors (BPBD Gunungkidul, PMI, PDAM) in the drought response are removed, the network appears to be irregular, unrelated, and independent of one another. This indicates that the central actors are in full control during the emergency period. The opportunity for actors who can take over the emergency control is from the Social Service of Gunungkidul Regency, although their network in the figure does not seem to embrace the private sector and NGOs, the Social Service of Gunungkidul Regency with all its capacities will turn into a crucial actor in the network.

\section{Closeness Centrality}

The next network measure is closeness centrality, which basically measures whether the distance among actors is close enough or far away. In the sense of closeness, it also shows the intensity of information sharing and cooperation among actors in the network. Three actors had a high level of closeness centrality, which indicated that they were relatively close to other members of 
Figure 5.

Graph of Inter-Organizational Networks Without the Central Actors

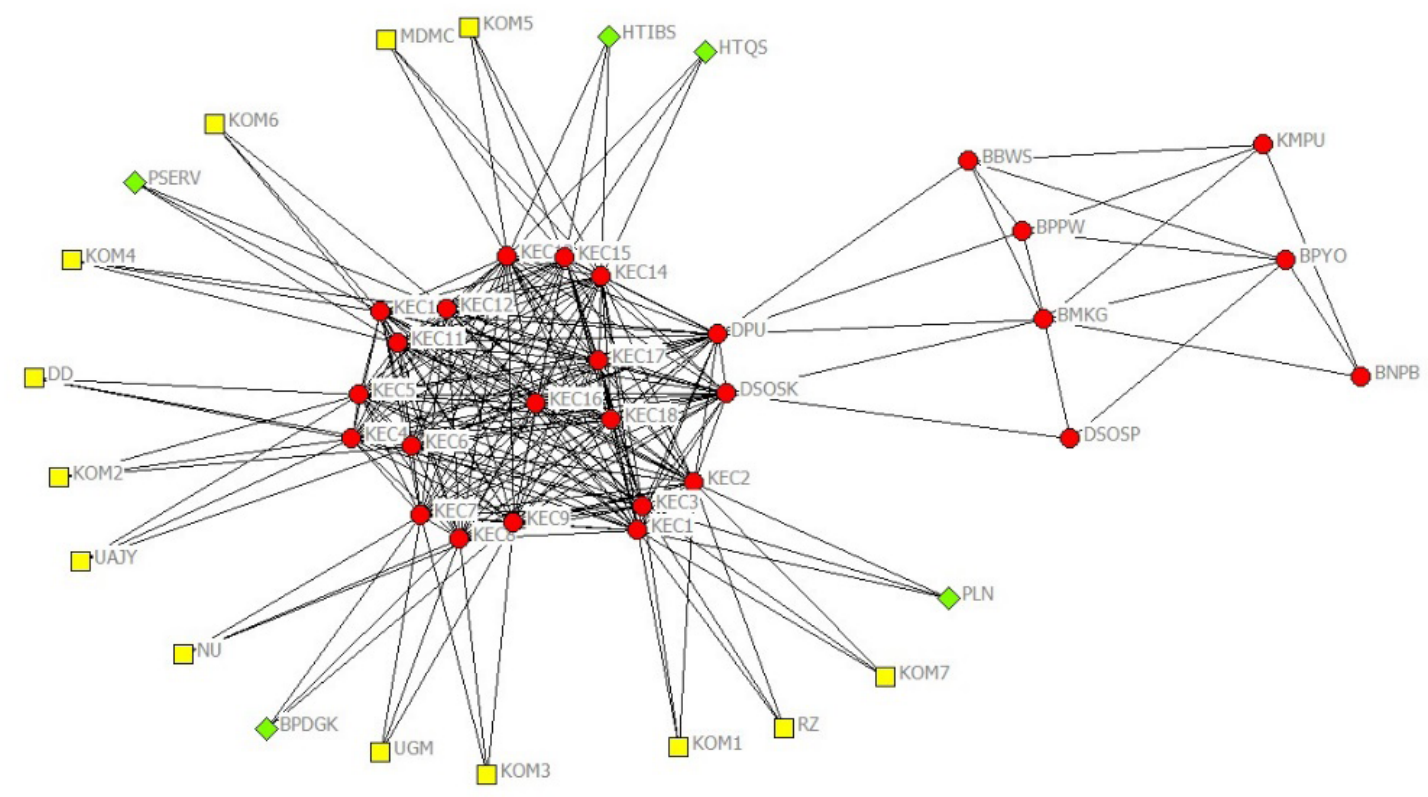

Source: Processed by the Authors

the network. As a result, they did not rely on other actors to communicate information and could convey information efficiently to other members. Table 4 shows that the organizational actors with the highest scores are the Regional Disaster Management Agency, PMI, and PDAM. These three actors have the highest scores in comparison to other actors/organizations.

Relevant to the argument by Prell (2012), in the concept of closeness centrality, the actors who are close to many other actors are very independent. These actors can quickly reach other people without relying heavily on intermediaries. Actors with high proximity centrality will also be seen as ones that can mobilize the network easier because they can reach everyone in the network easier.

\section{Role of Networks in the Government Level}

Network measurement using social network analysis in drought emergency response had been carried out based on a dataset consisting of 48 organizations carrying out 59 activities during the response period. All activities performed by
Table 4.

Closeness Centrality Measures

\begin{tabular}{|lcc|}
\hline \multicolumn{3}{|c|}{ CLOSENESS CENTRALITY MEASURES } \\
& Farness & nCloseness \\
& -------- & --- \\
BPBD & 48.000 & 97.917 \\
PMI & 62.000 & 75.806 \\
PDAM & 67.000 & 70.149 \\
KEC15 & 69.000 & 68.116 \\
DPU & 69.000 & 68.116 \\
KEC2 & 69.000 & 68.116 \\
KEC9 & 69.000 & 68.116 \\
KEC1 & 69.000 & 68.116 \\
KEC8 & 69.000 & 68.116 \\
KEC3 & 69.000 & 68.116 \\
\hline
\end{tabular}

Source: Processed by the Authors

the organizations were analyzed as presented in the diagram below.

Based on the figure above, the majority of drought response activities in the Gunungkidul Regency were carried out by the local government of Gunungkidul Regency (44\%). The district local government assisted by the affected subdistricts was very involved. Many disaster response activities carried out, including 
Figure 6.

Distribution of Actors in Networks

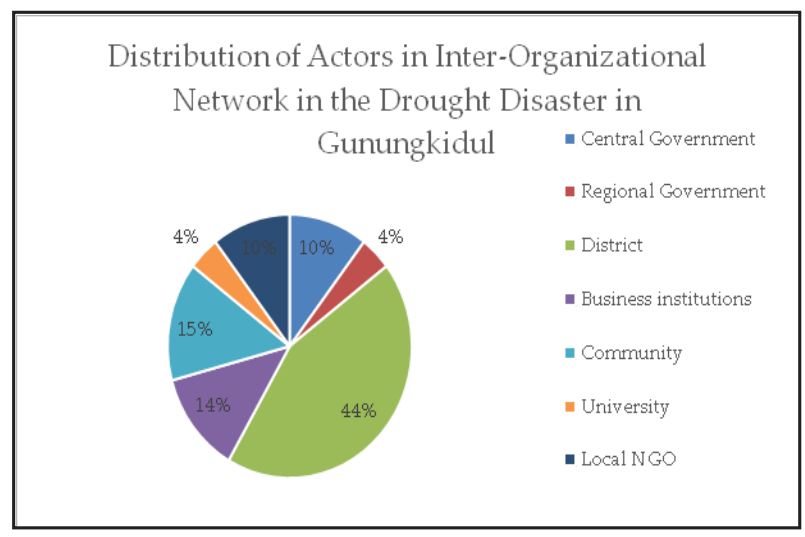

Source: Processed by the Authors

clean water distribution, water conservation, receiving assistance from various parties, policy formulation, public education, and weather forecasting. This data can be interpreted that the local government of Gunungkidul Regency was extremely confident in managing emergencies. This is in line with Waugh's (2000) statement that emergency management is the primary role of government. However, emergency management is not solely the responsibility of the government since a complex network of public, private, and civil society organizations and individuals is involved in it.

During the emergency response of drought in Gunungkidul Regency, 59 activities were carried out cooperatively, taking place from 2-20 September 2019. These activities were classified into six groups, including 27 activities of Water Distribution (DA), 4 activities of Water Conservation (KA), 20 activities of Donation (DON), 5 activities of policy formulation (KEB), 2 activities of Public Education (EP), and 1 activity of Weather Forecasting (PC). These activities were carried out by the 48 organizations described in the figure of actor distribution above.

It is in line with the concept of Kapucu and Demiroz (2017) that every level of network government can play a significant role in managing disasters and emergencies. The findings in this
Figure 7.

Organizational Activities During Research

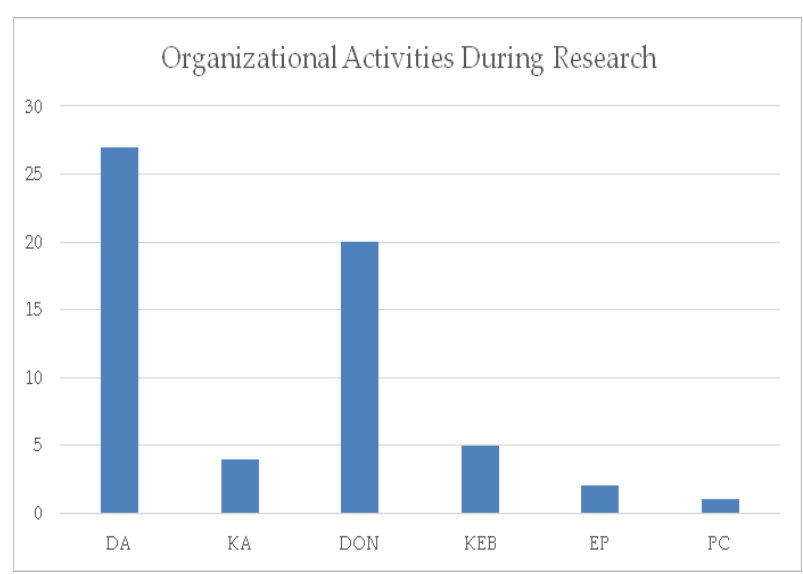

Source: Processed by the Authors

study at the national level show that national-level government organizations such as BNPB, Ministry of Public Works, and BMKG guided and provided advice to various levels of government (central, provincial, district/city) and non-government actors to work together in managing the drought disaster.

At the regional level, the BPBD of D.I Yogyakarta Province, the Social Services of D.I Yogyakarta Province, and the Public Works Office of the D.I Yogyakarta Province, had developed partnerships and networks to guide the effective management of disaster emergencies.

Meanwhile, at the local regency level, the Regional Secretary (in this case also as the Head of the BPBD of Gunungkidul Regency Ex Officio) as the emergency manager carried out command and control over the development of the situation, managed his strong network to respond to the drought disaster, which consisted of first responders, Operations Control Center or Pusdalops (EOC), districts, related agencies, local civil society organizations, local business institutions, et cetera. This network also opened up access to resources from business organizations, non-profit organizations, and community organizations that were inside and outside the command and control structure of emergency management. 


\section{Factors Affecting Networks}

Further discussion is about the factors influencing inter-organizational networks in emergency response of drought in Gunungkidul Regency. The analysis refers to the massive participation of the public, private, and non-profit sectors to make the emergency response a joint effort. Networking perceptions of disasters vary significantly due to differences in organizational purposes, objectives, and culture. The correct perception of the success of networking in emergency response is to see it as a mutual agreement about who will work effectively (Quarantelli, 1997 in Kapucu 2010).

\section{Multi-stakeholder Coordination}

The five most critical districts affected by the drought in Gunungkidul Regency, D.I Yogyakarta Province were Rongkop, Girisubo, Tepus, Panggang, Paliyan, Purwosari and Semin Districts. In mid-September 2019, the Regional Disaster Management Agency (BPBD) of Gunungkidul Regency received information from the BMKG that the start of the rainy season experienced delayed. Besides, BPBD had also estimated the strength of the budget for dropping clean water when the drought was predicted to get longer and wider and prepared the parties that could help to handle drought in Gunungkidul Regency. A budget crisis could affect the distribution of clean water to the community. The water crisis in the region was also getting worse because the water was increasingly difficult to find, causing the existing water sources to be invaded by water carrier tank trucks.

BPBD of Gunungkidul Regency coordinated to control the situation, updated data, and coordinated other organizations involved in drought disaster response. Besides BPBD, PMI of Gunungkidul Regency as a non-governmental organization also stated the importance of coordinating in dealing with increasingly uncertain situations.
PMI of Gunungkidul Regency coordinated with BPBD Gunungkidul Regency to fill in the gaps and minimized overlapping clean water assistance in the field and maximized the assistance coming even though PMI had access to larger aid donors. On the other hand, PDAM Gunungkidul Regency, as a regionally owned enterprise, highly needed coordination so that the drought response could be more integrated.

The bonding of organizational actors involved in disaster response made the situation and situation controllable. Positive support could also be seen from the districts affected by drought, that were actively involved in providing updated information and coordinating with the BPBD of Gunungkidul Regency as the district government authority in the field of disaster management.

Within a month, there were two coordination meetings chaired by the Regional Secretary of Gunungkidul Regency, attended by all units. Further, coordination was carried out within the Whatsapp (WA) Group that had been formed. Due to the distance and difficult landscape of Gunungkidul Regency, effective coordination through the WA Group was considered more possible.

This finding is in line with research conducted by Kapucu (2010) that coordination is an effort to eliminate redundancies (waste) in the environment during the disaster management process. Different people and different units can create an overlap, redundancy (waste) without coordination. Alternatively stated, coordination is a success (efficacy).

\section{Communication in Networks}

Such a massive drought disaster needs to be overcome by involving many parties, starting from the government, private sector, non-governmental organizations, and the community. Communication in the network is required so that disaster management activities are better coordinated, 
leading to effective and efficient coordination. The involvement of many parties in disaster management indicates that a communication system is running well. Communication dialogue between units involved in drought management is performed to monitor and update the development of clean water needs in the community.

Formal and informal communication determine the ongoing communication process in a network organization of emergency response and is considered effective. Formal communication is used when communicating in the system or is the hierarchy of the organization, which is very structural, usually done when formal coordination meetings and regular meetings take place. Meanwhile, informal communication is used when communication runs regardless of the system or hierarchy of a network organization.

Communication in a network is required to solve various problems, such as in assisting with the immediate needs for clean water of the community. It is essential to understand problemsolving in emergency response in the hope that everything runs according to plan, does not overlap, works well with volunteers in the field, takes place quickly, and reaches the right target so all part of the community is served. Apart from being a problem solver, there are needs for mutual understanding between organizations and good information transfer. When communication runs smoothly, the emergency response process can run smoothly as well. In addition to the problem information communicated by PMI, BPBD also added the problems communicated so that the problems faced can be immediately resolved. Expression of opinions used in communication in emergency response of drought is performed by providing opportunities to anyone who will convey information related to the drought disaster.

This finding is in line with Kapucu (2010) who explained that communication can help accelerate coordination through increasing mutual understanding among actors or organizations and transfer of information within and between organizations. Communication talks about how people understand each other and how information (not just "facts," but policies, prospects, rumors, feelings, failures, and all other human experiences) is transferred in an organization or network.

\section{Partnership}

Disaster management is no longer the matter of the government only but also business institutions and the community down to the family level as the main targets and actors in disaster management. Each sector has a role and responsibility in disaster management. There is a proverb saying that "disaster is everybody business". Therefore, in addition to involving government elements, involving those of business and civil society organizations will result in better disaster management.

In Gunungkidul Regency, disaster management had involved cross-sectoral actors in the formation process and meetings in the Disaster Risk Reduction Forum (DRR Forum). The DRR Forum at the village and regency levels had often held meetings. The last meeting was on June 15, 2019, discussing the theme of "The Strategic Role of the Disaster Risk Reduction Forum in Sustainable Development without Risks". However, the activities of the DRR Forum in the context of this drought disaster had not shown any real activities. It can be seen, therefore, that activities in disaster risk reduction were separate from other activities during emergency response.

There had not been a formal partnership, where the actors or organizations involved in disaster management did not yet have formal agreements in the form of an MoU or other forms of agreement. Regarding disaster preparedness, the agreements between these stakeholders were contained in a contingency planning document or commonly referred to as renkon documents. With this document, it is hoped that later, either BPBD 
or related parties, can plan quickly and precisely how to take steps to handle potential natural disasters around.

The absence of formal agreements commits network members involved in handling drought disasters invisible. Even so, the partnership in handling drought is a vital element and currently, the partnership is still informal, or in other words, the partnership is based on mutual trust (trustbased). This partnership is not limited to just one sector but includes all sectors, even non-sectoral partners such as the community. The main partners in emergency response are the public, private and non-profit sectors, the media, and the public. Partnerships are not only horizontal but also vertical.

In carrying out its duties and functions as a disaster management coordinator, BPBD was always open to those who offered help. Regarding parties that intended to help but not through coordination with BPBD, the Rapid Reaction Team and Pusdalops of BPBD continued to monitor reports from both the public and the village and district government.

This finding is in line with the partnership concept of Kapucu (2010), that the partnership carried out in the emergency response period will eliminate hurdles in the emergency response process by increasing the available resources.

\section{Interoperability}

In terms of technical operation, interoperability is a significant matter to consider because it relates to ways of sharing resources and exchanging data. When the leaders of the organization have coordinated and partnered, this interoperability in the field becomes the key target for accelerating control of emergencies.

In Gunungkidul Regency, all organizations that have often worked together in disaster management are pretty easy to help each other. Other organizations that need assistance will definitely be helped. Likewise, the disclosure of information and data held by BPBD and other parties such as PMI can ease other organizational actors to participate to help with drought management needs. The openness of data and information and mutual understanding between organizations are the keys to establishing interoperability in the field.

When technical problems are resolved collectively and in the same language, the emergency response process will be easier to control. This is in line with the concept described by Kapucu (2010), that one of the factors affecting inter-organizational networks in emergency management is interoperability. Interoperability is the understanding of how different partners come together and use their resources together, how they work together, and how they talk together.

\section{Decision Making}

Emergency management managers are challenged to make difficult decisions whenever a disaster occurs. For the most part, decisions are made based on the principle of emergency response, which is to save as many lives as possible. Data, information, science, and technology also support decision making in emergency response. Inputs of weather forecasts from the $\mathrm{BMKG}$, information on the river or groundwater discharge from the Major Agency of River Basin, KemenPUPERA, and drought risk studies from Gadjah Mada University were all taken into consideration in making decisions.

Decision making in an emergency response network is built from the bottom up and is not enforced by top-down authorities, in which the end goal is not a hierarchical order. The decisionmaking process is more horizontal since reliance on vertical relationships will consume a lot of energy.

Kapucu (2010) described decision making, where many argue that networking is not suitable in situations where a rapid decision-making 
process is required such as in an emergency. However, the habit of working together that is built through social relationships can substantially increase the speed of decision making.

\section{Leadership}

The success of leadership is its ability to provide positive changes in the environment. As a leader, one must be able to think about how to face and win a change. The capability of a leader is a milestone in the success of the organization and the team in achieving common goals. As occurred in several disasters, the community affected by disasters can get through periods of crisis because of the presence of a leader to stop the crisis.

In times of such a crisis, the ability to make proper and fast decisions is a key requirement for a leader. The regional leader, in this case, the Regional Secretary of Gunungkidul Regency, emphasized that the community would be easily provoked into anger if the government could not react quickly enough to provide clean water and humanitarian assistance. This condition could worsen the situation if there was an uneven distribution of assistance. Regional leaders must have a high quality of ability to coordinate with various parties and establish relationships with communities during periods of uncertainty by making decisions, providing mechanisms, and plans on how to provide clean water and humanitarian assistance to communities in the districts and villages.

Regional Secretary of Gunungkidul Regency as a public manager is at the forefront of responding to an increasingly complex emergency. He was able to deal with a variety of players or actors and can comprehend information derived from sources using his jargon in general. Based on this input from various information, strategies and quick but measurable decisions could be made.

At the regional and central government levels, the trust to control the drought crisis was fully given to the Regional Government of
Gunungkidul Regency. The leadership of the Gunungkidul Regional Government was entirely supported by the government level above. The Regional Government of Gunungkidul in solving drought problems used a human relations approach, the ability to inspire network members through a common vision and mission, and an approach that involves organizational members.

Regional Government of Gunungkidul Regency could coordinate networks at various levels of government and various organizational actors involved, both from the private sector, NGOs, and volunteers. The Regional Secretary in carrying out the leadership function in the drought response was at the center of the network in the ordering process and disseminated relevant information to the parties.

This is in line with what was expressed by Kapucu (2010) about leadership that the general public expects strong leadership to fight against man-made threats. Strong leadership has been associated with a strong command structure.

\section{Information Technology (IT)}

The use of information technology at BPBD was very minimal (insufficient), both in terms of network infrastructure, computers (hardware), and in the use of software for disaster data management. Although currently, the National Agency for Disaster Countermeasure (BNPB) has had a disaster information system (dibi. bnpb and geospasial.bnpb), although the system has not been effectively used in the regions, and BPBD has not been integrated into the system. Therefore, we need an information system that can accommodate BPBD interactions in inputting and managing disaster data in the regions, which is integrated with existing information systems at BNPB and other agencies.

BPBD in using Information Technology tools remained very limited, but PMI's involvement in the emergency response network could provide input in terms of making maps of Geographical 
Information Systems. This technology has been widely used to create digital and paper maps to increase situational awareness of emergency by decision-makers.

In sharing disaster information, organizations have a key role to play. The flow of information planned before a disaster can also provide support for an effective response. Even though various technological systems offer effective communication, compatibility between various technologies and disaster situations is also required.

The findings in the factor of Information Technology (IT) are relevant to Kapucu's (2010) study that revealed that IT applications can play a crucial role in emergency management networks. The problem of effective inter-agency communication among organizations and the role of IT can achieve the objectives of effective communication and decision making in an emergency.

\section{Conclusion}

This paper has presented the use of the Social Network Analysis (SNA) and qualitative methods of inter-organizational networks during the emergency response of drought in Gunungkidul Regency. Some of the good points can be summarized as follows. The limited institution, human resource, financial, and technical capabilities do not prevent the BPBD (as the disaster management authority in Gunungkidul Regency) from being silent. By utilizing and maximizing existing networks, the emergency can be controlled. The networking ability of Gunungkidul Regency is a type of operative adaptation which is indicated in the steps of organizational flexibility in the ability to adapt to changing situations.

The role of inter-organizational networks at the district level has been optimized by conducting command and control over the development of the situation, organizing a strong self-owned network to respond to the drought disaster, opening up access to resources from business institutions, non-profit organizations, and community organizations in inside and outside the command and control structure of emergency management.

Seen from the SNA analysis, the central actors in an emergency response included the BPBD, PMI, and PDAM of Gunungkidul Regency. BPBD had the highest centrality since most of the resources flow to the BPBD which worked and was directly responsible for controlling the drought disaster situation, either donation resources or sharing knowledge information. Meanwhile, PMI held the centrality because several donor agencies that would provide assistance had good relations with PMI before finally having to coordinate with BPBD of Gunungkidul Regency. Meanwhile, the PDAM had the centrality due to a large part of its work was receiving complaints from the community in each district.

Factors affecting inter-organizational networks in emergency response of the drought show positive results. Inter-organizational networks could coordinate to control the situation, updated data, and coordinated other organizations involved in the drought disaster response. In network communication, all network members were provided the freedom and opportunity to express opinions according to their capacity and used factual data validly, which was very much needed, particularly in preventing hoax issues that were easily disseminated among the public. The partnership was informal, in other words, they were trust-based partnerships. The openness of data and information and mutual understanding among organizations were the keys to establishing interoperability in the field. Habits of working together that was built through social relationships could substantially increase the speed of decision making. The Reginal Secretary's ability could inspire network members through a common vision and mission. 
The results show that several factors are causing inter-organizational networks to be less than optimal, including:

1. A centralized inter-organizational network is extremely useful for the initial phase of a disaster in forming groups and building support for collective action. However, centralized networks also have unfavorable disadvantages for long-term planning and problem solving, given the drought disaster is a type of slow onset and prolonged disaster.

2. Some deficiencies in the factors of interorganizational networks that can be improved include partnerships and information technology. There was no partnership in terms of making agreements in the preparedness phase through a link and match of the DRR Forum and making agreements in a contingency plan document that was easy to implement. Meanwhile, in information technology, the quality and integration of information systems between organizational units were still poor.

\section{Recommendation}

In managing the network for a relatively long time, it is significant to utilize a decentralized network structure with a horizontal approach or to create cluster groups. The division of authority to other organizational actors results in a more effective and efficient quality of emergency response.

1. Link and match DRR forum activities, so that partnership cooperation activities of pre-and post-disaster continue sustainably, not only separated from pre-disaster activities.

2. Upgrading and integrating the information system is a must. By improving the quality and integrating information systems among organizational units, disaster management can be performed faster and more effectively.

3. The use of SNA in this study was quite successful in representing a cross-actor and multi-stakeholder picture of disasters.
The results of this SNA analysis can also be utilized as a material for the formulation of emergency management policies. Further, public administration studies can provide novelty to these policy inputs.

\section{References}

Adhi, T.N. (2011). Pemisahan aliran dasar bagian Hulu Sungai Bribin pada Aliran Gua Gilap, di Kars Gunung Sewu, Gunung Kidul, Yogyakarta, Jurnal Geologi Indonesia, 6(3).

Borgatti, S. P., Everett, M.G., \& Johnson, J. C. (2013). Analyzing Social Networks. London: Sage.

Climatology Station of Meteorological, Climatological, and Geophysical Agency of Yogyakarta. (2019). Prakiraan Musim Hujan 2019/2020 D.I Yogyakarta, Sleman, Special Region of Yogyakarta.

Comfort, L. K. (1999). Shared risk: complex systems in seismic response, $1^{\text {st }}$ ed. Pergamon, Amsterdam; New York.

Djalante, R. (2012). Adaptive governance and resilience: the role of multi-stakeholder platforms in disaster risk reduction. Natural Hazards and Earth System Sciences. doi: 10.5194/nhess-12-2923-2012.

Food and Agriculture Organization (FAO). (2017). Drought response: our framework for England, Bristol.

Freeman, L. C. (2004). The Development of Social Network Analysis A Study In The Sociology of Science. Book Surge, LLC North Charleston, South Carolina: Empirical Pres.

Fritz, C. E. (1961). Disaster. In Merton, R.K. and Nisbet, R.A. (Eds)., Contemporary Social Problems, Harcourt, Brace and World, New York, USA.

Gregg, C. E., \& Houghton, B. F. (2006). Natural Hazards, In Paton and Johnston, Disaster Resilience: An Integrated Approach. Springfield, Illinois, USA.

Gunungkidul Regency Disaster Management Agency (BPBD). (2016) Peta Risiko 
Kekeringan Kabupaten Gunungkidul. Gunungkidul, Wonosari: Gunungkidul Regency Disaster Management Agency (BPBD).

Gunungkidul Regency Disaster Management Agency (BPBD). (2018). Laporan Bulanan Bencana Kekeringan. Gunungkidul, Wonosari: Gunungkidul Regency Disaster Management Agency (BPBD).

Gunungkidul Regency Disaster Management Agency (BPBD). (2019). Laporan Bulanan Bencana Kekeringan. Gunungkidul, Wonosari: Gunungkidul Regency Disaster Management Agency (BPBD).

Kapucu, N. (2010). Collaborative Emergency Management and National Emergency Management Network. Disaster Prevention and Management, 19(4), 452-468. Doi: 10.1108/09653561011070376.

Kapucu, N., \& Demiroz, F. (2017). Interorganizational Networks in Disaster Management. Social Network Analysis of Disaster Response, Recovery, and Adaptation. http://dx.doi.org/10.1016/ B978-0-12-805196-2.00003-0

Kauffman, S. (1993). The Origins of Order: SelfOrganization and Selection in Evolution. New York: Oxford University Press.

Koppenjan, J., \& Klijn, E.H. (2004). Managing Uncertainties in Networks: A Network Approach to Problem Solving and Decision Making, Routledge: New York.

Krebs, Valdis. (2008). Social Network Analysis, A Brief Introduction. Retrieved October 13, 2019 from http://www.orgnet.com/sna. html

Kusumasari, B. (2014). Manajemen Bencana dan Kapabilitas Pemerintah Lokal. Yogyakarta: Gava Media,

Kusumasari, B., Alam, Q., \& Siddiqui, K. (2010). Resource Capability for Local Government in Managing Disaster. Disaster Prevention and Management, 19(4), 438-451. https://doi. org/10.1108/09653561011070367
Lindell, M. K., Perry, R. W \& Prater, C. (2007). Introduction to emergencymanagement, Wiley; Chichester: Hoboken, N.J, USA.

McEntire, D.A. (2002). Coordinating multi\#organisational responses to disaster: lessons from the March 28, 2000, Fort Worth tornado. Disaster Prevention and Management: An International Journal, 11(5), 369 - 379. http://dx.doi. org/10.1108/09653560210453416

Meduri, Y. (2016). Multi-stakeholder participation in disaster recovery: A case study, doi: 10.1016/j.proeng.2016.08.153.

Meteorological, Climatological, and Geophysical Agency (BMKG). (2019). Jumpa Pers Prediksi Iklim Tahun 2020. Retrieved November 13, 2019 from https://www.bmkg.go.id/ berita/?p=jumpa-pers-terkait-prediksiiklim-tahun-2020-dan-updte-gempabumiyang-melanda-mindanao\&lang $=$ ID

Moleong, L. J. (2005). Metodologi penelitian kualitatif. Bandung: PT. Remaja Rosdakarya.

National Disaster Management Authority (BNPB). (2013). Indeks Risiko Bencana Indonesia, Jakarta: National Disaster Management Authority (BNPB).

National Disaster Management Authority (BNPB). (2014). Rencana Nasional Penanggulangan Bencana 2015 - 2019, Jakarta: National Disaster Management Authority (BNPB).

National Disaster Management Authority (BNPB). (2016). Risiko Bencana Indonesia, Jakarta: National Disaster Management Authority (BNPB).

Prasetyo, Dwi. (2013). Kerentanan wilayah terhadap kekeringan menggunakan metode analytical hierarchy process (Studi Kasus: Kabupaten Gunungkidul).Jurnal Kerentanan Wilayah.

Prell, C. (2012). Social Network Analysis: History, Theory \& Methodology. Los Angeles: Sage.

Prell, C., Hubacek, K. \& Reed, M. (2009). Stakeholder Analysis and Social Network Analysis. 
Natural Resource Management, Society and Natural Resources, 22(6), 501-518. https:// doi.org/10.1080/08941920802199202

Scott, J., \& Carrington, P. J. (2011). The SAGE Handbook of Social Network Analysis. LA: Sage Publication.

Tallaksen, L.M., Kingston, D.G., Stagge, J.H., \& Hannah, D.M. (2015). Europeanscale Drought: Understanding Connections Between Atmospheric Circulation and Meteorological Drought Indices. Journal of Climate. doi: 10.1175/JCLID1400001.1.
Twigg, J. (2015). Disaster Risk Reduction: Good Practice Review. London: Overseas Development Institute

United Nations International Strategy for Disaster Reduction (UNISDR). (2009) Terminology on Disaster Risk Reduction, Geneva, Switzerland. Wasserman, S., \& Faust, K. (1994). Social Network Analysis: Methods and Applications. New York and Cambridge: Cambridge University Press. Waugh, W. L. Jr. (2000.) Living with Hazards Dealing with Disasters: An Introduction to Emergency Management. ME Sharpe: Armonk, New York: Routledge. 